\title{
Reduction of Inflammation and Enhancement of Motility after Pancreatic Islet Derived Stem Cell Transplantation Following Spinal Cord Injury
}

\author{
Erdal Karaoz, Ph.D., ${ }^{1-3}$ Filiz Tepekoy, Ph.D., Irem Yilmaz, M.Sc., ${ }^{3}$ Cansu Subasi, M.Sc., ${ }^{3}$ Serdar Kabatas, M.D. ${ }^{4}$ \\ Department of Histology \& Embryology, Faculty of Medicine, Istinye University, Istanbul, Turkey \\ Center for Stem Cell and Tissue Engineering Research \& Practice, ${ }^{2}$ istinye University, Istanbul, Turkey \\ Center for Regenerative Medicine and Stem Cell Research \& Manufacturing (LivMedCell), Istanbul, Turkey \\ Neurosurgery Clinic, ${ }^{4}$ Gaziosmanpasa Taksim Training and Research Hospital, Istanbul, Turkey
}

Objective : Spinal cord injury (SCl) is a very serious health problem, usually caused by a trauma and accompanied by elevated levels of inflammation indicators. Stem cell-based therapy is promising some valuable strategies for its functional recovery. Nestinpositive progenitor and/or stem cells (SC) isolated from pancreatic islets (PI) show mesenchymal stem cell (MSC) characteristics. For this reason, we aimed to analyze the effects of rat pancreatic islet derived stem cell (rPI-SC) delivery on functional recovery, as well as the levels of inflammation factors following SCl.

Methods : rPI-SCs were isolated, cultured and their MSC characteristics were determined through flow cytometry and immunofluorescence analysis. The experimental rat population was divided into three groups : 1) laminectomy \& trauma, 2) laminectomy \& trauma \& phosphate-buffered saline (PBS), and 3) laminectomy+trauma+SCs. Green fluorescent protein (GFP) labelled rPI-SCs were transplanted into the injured rat spinal cord. Their motilities were evaluated with Basso, Beattie and Bresnahan (BBB) Score. After 4-weeks, spinal cord sections were analyzed for GFP labeled SCs and stained for vimentin, S100 brain derived neurotrophic factor (BDNF), 2',3'-cyclic-nucleotide 3'-phosphodiesterase (CNPase), vascular endothelial growth factor (VEGF) and proinflammatory (interleukin [IL]-6, transforming growth factor [TGF]- $\beta$, macrophage inflammatory protein [MIP]-2, myeloperoxidase [MPO]) and anti-inflammatory (IL-1 receptor antagonis) factors.

Results : rPI-SCs were revealed to display MSC characteristics and express neural and glial cell markers including BDNF, glial fibrillary acidic protein (GFAP), fibronectin, microtubule associated protein-2a,b (MAP2a,b), $\beta 3$-tubulin and nestin as well as antiinflammatory prostaglandin E2 receptor, EP3. The BBB scores showed significant motor recovery in group 3. GFP-labelled cells were localized on the injury site. In addition, decreased proinflammatory factor levels and increased intensity of anti-inflammatory factors were determined.

Conclusion : Transplantation of PI-SCs might be an effective strategy to improve functional recovery following spinal cord trauma.

Key Words : Spinal cord $\cdot$ Wounds and injuries · Islets of langerhans $\cdot$ Stem cells $\cdot$ Regeneration.

\footnotetext{
- Received : February 9, 2018 •Revised : March 30, 2018 •Accepted : June 23, 2018

- Address for reprints : Erdal Karaoz, Ph.D.

Department of Histology \& Embryology, Faculty of Medicine, İstinye University, Maltepe Mahallesi, Edirne Cirpici Yolu, No:9, Cevizlibag, İstanbul 34010, Turkey Tel : +90-212-481-36-55, Fax : +90-212-481-36-88, E-mail : ekaraoz@hotmail.com
}

This is an Open Access article distributed under the terms of the Creative Commons Attribution Non-Commercial License (http://creativecommons.org/licenses/by-nc/4.0) which permits unrestricted non-commercial use, distribution, and reproduction in any medium, provided the original work is properly cited. 


\section{INTRODUCTION}

Spinal cord injury (SCI) is a detrimental event mainly caused by a trauma ${ }^{7)}$, that can lead to physical disability including failure in motor, sensory or autonomic function ${ }^{35}$. SCI affects patients physically and psychologically as well as their financial condition ${ }^{15}$. SCI respectively causes edema, decreased blood flow, vasospasm, free radical production, inflammation, excitotoxicity, lipid peroxidation and finally ischemia provoke cell apoptosis ${ }^{46)}$. Due to the non-responsive environment of the injured spinal cord, axon regeneration does not occur ${ }^{58)}$. Besides, the loss of function after SCI might be caused by both the primary mechanical insult and multifaceted secondary degenerative response ${ }^{50)}$.

Some experimental studies in the last decades, proved that the injured spinal cord could be restored ${ }^{50)}$. Nowadays, stem cell based therapy is promising some valuable strategies for functional recovery of the injured spinal cord ${ }^{(2)}$. In this context, mesenchymal stem cells (MSCs) were used in addition to neural progenitor stem cells for functional recovery ${ }^{40)}$.

The mechanism of stem cell therapy in neurodegenerative diseases include support to neuronal growth, replacement of neuronal cells, preservation of glial cells, increasing trophic molecules, remyelination of axons, regeneration of damaged synaptic connections ${ }^{33,51)}$. Stem cells also have the potential for angiogenesis, bridging of cavities, reducing inflammation and stimulation of endogenous precursor cells for neuronal plasticity $^{33)}$ besides their anti-apoptotic effect ${ }^{51)}$. In addition to their capability of differentiation and renewal, stem cells secrete substances that promote neuroprotection, such as cytokines, growth factors and trophic factors ${ }^{54)}$.

MSCs have become one of the crucial cell sources for the treatment of neurodegenerative conditions ${ }^{24)}$. The source for MSC for therapeutic purposes can be the bone marrow ${ }^{23}$, cord blood $^{30)}$, adipose tissues ${ }^{14)}$, and dermis ${ }^{39)}$.

First described by Zulewski et al. ${ }^{63)}$, nestin-positive progenitor and/or stem cells (SC) isolated from human and murine pancreas have been shown to include phenotypic markers identical to MSCs ${ }^{11,63)}$. These cells have the capability of proliferating and differentiating into insulin-producing cells, mesodermal and ecto-mesodermal germ layer derived somatic cells such as adipocytes and osteocytes in vitro ${ }^{63)}$. Additionally, nestin positive MSCs are considered to be a reliable source for central nervous system (CNS) repair ${ }^{31}$.
Besides being a derivation of embryonic endoderm, pancreatic islets share similar phenotypic traits with neurons ${ }^{13)}$. In addition to the presence of insulin gene transcription in the vertebrate brain ${ }^{12)}$, recent studies suggest that pancreatic beta cells share common alternative splicing regulators and programs with neurons ${ }^{25)}$, proving that similarities continue at post-transcriptional level as well. Moreover, mouse pancreatic epithelial cells can give rise to neuron-like cells ${ }^{44)}$.

Rat pancreatic islet derived stem cell (rPI-SCs) have been reported to represent the characteristics of MSCs ${ }^{47)}$. In our previous studies, we have also demonstrated the expression of neurogenic (eno2, microtubule associated protein-2a,b, c-fos, nestin, glial fibrillary acidic protein [GFAP], and $\beta 3$-tubulin) and osteogenic (osteonectin, osteocalcin, osteopontin, runx2, bone morphogenetic protein [BMP]-2, BMP-4, and type-I collagen) markers in $\mathrm{rPI}-\mathrm{SCs}^{26)}$.

In this study, we aimed to investigate the effects of rPI-SCs transplantation on functional recovery and neural regeneration processes following SCI, as well as reduction of proinflammatory factors within the injured spinal cord.

\section{MATERIALS AND METHODS}

\section{Animals}

The SCI study included about 2-3 months old 15 female, nonpregnant and five male Wistar albino rats with a weight of $200-300 \mathrm{~g}$. In the first step of the study, five rats (male) were sacrificed in order to obtain rPI-SCs. The remaining rats were divided into three groups (five rats per group) : laminectomy+ trauma (group 1), laminectomy+trauma+phosphate-buffered saline (PBS) (group 2); laminectomy+trauma+SCs (group 3). Rats were sacrificed 4 weeks after transplantation. The Ethics Committee of Kocaeli University approved the experimental design and all procedures with a IACUC protocol number of KOU/HAYDEK 1/2/2013.

\section{Culture of rPI-SCs}

The pancreatic islets were isolated as described previously ${ }^{26}$ and cultured in RPMI 1640 (Invitrogen/GIBCO, Grand Island, NY, USA) with glucose $2 \mathrm{~g} / \mathrm{L}$ supplemented with $10 \%$ fetal bovine serum (FBS; Invitrogen/GIBCO), $100 \mathrm{IU} / \mathrm{mL}$ penicilin-100 $\mu \mathrm{g} / \mathrm{mL}$ streptomycin (Invitrogen/GIBCO) and glutamine $(2 \mathrm{mmol} / \mathrm{L}$; Invitrogen/GIBCO $)$ at $37^{\circ} \mathrm{C}$ in a hu- 
midified air atmosphere containing $5 \% \mathrm{CO}_{2}$. Some islets immediately adhered to the surfaces of the flasks. Within several days, a monolayer of cells was observed growing out and away from the islets and after 13 to 15 days of culturing, cells in the monolayer reached to $70 \%$ confluency and named as passage zero $\left(\mathrm{P}_{0}\right)$ cells. For passaging, the cells were washed with $\mathrm{Ca}^{2+}$ $\mathrm{Mg}^{2+}$ free phosphate-buffered saline (PBS) (Invitrogen/GIB$\mathrm{CO}$ ) and detached by incubating with $0.25 \%$ trypsin-ethylenediaminetetraacetic acid solution (Invitrogen/GIBCO) for 5-10 minutes at $37^{\circ} \mathrm{C}$. After addition of growth medium to inactivate trypsin, the cells were then centrifugated at $200 \mathrm{~g}$ for 10 minutes, resuspended in $1 \mathrm{~mL}$ complete medium, counted in duplicate using Thoma chamber and then plated in $75 \mathrm{~cm}^{2}$ flasks (BD Biosciences, San Diego, CA, USA) at densities of $1 \times$ $10^{6}$ cells/flask. The growth medium was replaced every 3 days over a 10-14 day period.

\section{Flow cytometry}

To confirm that rPI-SCs maintain their phenotypic characteristics after growth in culture, undifferentiated SCs were subjected to flow cytometry analysis. The surface markers of rPI-SCs at passages $3\left(\mathrm{P}_{3}\right)$ were assayed with antibodies against the following rat antigens : CD29 (integrin $\beta 1$ chain), CD45 (leukocyte common antigen), CD54 (intercellular adhesion molecule-1), CD90 (Thy-1/Thy-1.1), CD106 (vascular cell adhesion protein-1), major histocompatibility complex (MHC) classes I and II and their three isotype controls (IgG2a, $\kappa)$.

All of the antibodies were supplied by Becton Dickinson (BD Biosciences). Flow cytometry was performed using a FACSCalibur (BD Biosciences). The data were analyzed with Cell Quest software (BD Biosciences).

\section{Labeling with green fluorescent protein (GFP) of rPI-SCs}

Green fluorescent protein (GFP) (Clontech, Palo Alto, CA, USA) was transfected by electroporation (Neon Transfection System; Invitrogen, Carlsbad, CA, USA) with respect to the instructions provided by the manufacturer. The transformed cells were cultured in $1 \mathrm{~mL}$ minimum essential media-medium with 15\% FBS. After 48 hours of incubation, the cells were selected with respect to the resistance against G418 $(200 \mu \mathrm{g} / \mathrm{mL})$.

\section{Surgical procedure and cell transplantation}

For skin preparation of T10-T11 spinal cord surgery, lum- bar laminectomy of tracer injection, dermal surface of the related regions was cleared by hair razor, and the skin was washed by antibacterial soap followed with betadine and $70 \%$ ethanol application ${ }^{8)}$. After an overnight fast with unrestricted access to water, all 15 rats were anesthetized with intramuscular ketamine $(50 \mathrm{mg} / \mathrm{kg})$ and xylazine $(5 \mathrm{mg} / \mathrm{kg})$ prior to surgery. Under dissection stereomicroscope; $3 \mathrm{~mm}$ long laminectomy, encompassing the caudal end of T10 vertebra and the rostral end of T11 vertebra, was performed. For SCI groups (total, 15), after the laminectomy, the animals were moved to stabilization platform. The spine was immobilized stabilizing clamps and a severe T10-T11 contusive injury was introduced by dropping the impounder rod $(1 \mathrm{~g})$ from a height of $50 \mathrm{~mm}$. The muscle and fascia layers were sutured and the skin was stapled subsequently.

GFP labeled rPI-SCs $\left(3 \times 10^{5}\right.$ cells $\left./ 5 \mu \mathrm{L}\right)$ were transplanted into the injured spinal cord via Hamilton syringe (Hamilton Company, Reno, NV, USA) connected to a syringe pump (KD Scientific Inc., Holliston, MA, USA) for 5 minutes, respectively. PBS group received $5 \mu \mathrm{L}$ of PBS at the injured spinal cord with the same technique. The needle was removed 10 minutes after intraspinal transplantation, and muscle \& skin layers were closed in layers. The bladders of SCI rats were evacuated twice daily during the entire study.

\section{Beattie and Bresnahan (BBB) scoring-functional tests}

Functional tests were performed using the BBB locomotor rating scale at pre-surgery, at days $1,7,14,21$, and 28 postinjury (p.i.). Two independent, blinded examiners observed each animal for 4 minutes. Hindlimb movements were recorded by video camera and locomotor functions were assessed ${ }^{5)}$. The $\mathrm{BBB}$ scores were presented as mean \pm standard error.

\section{Tissue harvesting and immunoflourescence ex- amination}

At the end of 4 weeks, rats were anesthetized with ketamine (75 mg/kg, i.p.) and xylazine (20 mg/kg, i.p.) and transcardially perfused with saline $(150 \mathrm{~mL} /$ per animal) and followed with $4 \%$ neutral buffered paraformaldehyde in $0.1 \mathrm{~mol} / \mathrm{L} \mathrm{PBS}$, $\mathrm{pH}$ 7.4. One $\mathrm{cm}$ spinal cord segment encompassing the injury site was removed, the tissues were post-fixed in 4\% paraformaldehyde approximately 24 hours and then tissues were dehydrated through a graded series of ethanol, cleared with xy- 
lene and finally embedded in paraffin wax.

To perform cell tracing after injection of the GFP labeled rPI-SCs, an immunofluorescence double staining protocol was performed on sections. Slides were deparaffinized with two changes of xylene for 5 minutes each and rehydrated in a series of graded alcohol solutions. Sections were antigen retrieved using a steamer-citrate buffer antigen retrieval method. Endogenous peroxidases were inhibited by incubation with fresh $3 \% \mathrm{H}_{2} \mathrm{O}_{2}$ in PBS buffer. Nonspecific staining was blocked with the mixture of two different serums at $1.5 \%$ in PBS for 30 minutes at room temperature. The sections were incubated in a mixture of two primary antibodies (Table 1) in a pairwise fashion with the mouse monoclonal anti-GFP antibody (sc-9996) for 1 hour at room temperature and appropriate secondary antibodies 30 minutes at room temperature. The mounted cells with mounting medium containing DAPI (Santa Cruz Biotechnology, Santa Cruz, CA, USA), were examined under fluorescence microscope. Immunoflourescence stainings on the $\mathrm{P}_{3}$ cells were performed as previously described $^{26)}$. The evaluation of the immunoflourescence stainings were accomplished by ImageJ program (National Institutes of Health, Bethesda, MD, USA) as described previously ${ }^{49}$. Briefly, corrected total cell fluorescence was determined through the integrated density, area and the mean gray value of the cells.
All experiments were repeated a minimum of three times. All data presented as mean \pm standard error. All statistical analyses were performed using SPSS version 10.0 (SPSS Inc., Chicago, IL, USA). The data were analyzed using one-way analysis of variance. Differences between groups were regarded as statistically significant when $p<0.05$.

\section{RESULTS}

\section{Isolation, culture and phenotype identification of SCs from rPIs}

Examination of cultured islets under an inverted microscope showed that they had regular cellular structures (Fig. 1A). rPI-SCs spread on culture flask from islets and attached to the culture flasks sparsely, and the majority of cells displayed a fibroblast-like, spindle-shaped morphology during the early days 20 of explant culture incubation. rPI-SCs reached a monolayer confluence in the primary culture on 12-15 days 1 of being plated in their first passages. Most of the rPI-SCs exhibited large, flattened or fibroblast-like morphology in the later passages (Fig. 1B and C). We confirmed that rPI-SCs maintained their phenotypic characteristics after growth in culture and undifferentiated SCs were subjected to flow cytometry. Flow cytometry analysis revealed that, specif-

Table 1. Primary antibodies used for immunofluorescence analysis

\begin{tabular}{lccl}
\hline Antibody & Dilution & Source & Provider \\
\hline BDNF & $1: 100$ & Rabbit & Santa Cruz Biotechnology sc-20981 \\
Fibronectin & $1: 100$ & Mouse & Santa Cruz Biotechnology sc-81767 \\
Vimentin & $1: 100$ & Goat & Santa Cruz Biotechnology sc-7557 \\
B3-tubulin & $1: 50$ & Mouse & Santa Cruz Biotechnology sc-69965 \\
Nestin & $1: 50$ & Mouse & Santa Cruz Biotechnology sc-33677 \\
IL-1ra & $1: 50$ & Rabbit & Santa Cruz Biotechnology sc-25444 \\
EP3 & $1: 100$ & Goat & Santa Cruz Biotechnology sc-16019 \\
MAP2a,b & $1: 100$ & Mouse & Thermo Scientific MA5-12823 \\
GFAP & Mouse & Thermo Scientific MS-280-R1 \\
Anti-GFP & $1: 100$ & Mouse & Santa Cruz Biotechnology sc-9996 \\
CNPase & $1: 200$ & Rabbit & Thermo Scientific PA5-29345 \\
S100 & $1: 100$ & Goat & Santa Cruz Biotechnology sc-7851 \\
VEGF & $1: 300$ & Goat & Santa Cruz Biotechnology sc-1836 \\
\hline
\end{tabular}

BDNF : brain derived neurotrophic factor, IL-1ra : interleukin-1 receptor antagonis, MAP2a,b : microtubule associated protein-2a,b, GFAP : glial fibrillary acidic protein, GFP : green fluorescent protein, CNPase : 2',3'-cyclic-nucleotide 3'-phosphodiesterase, VEGF : vascular endothelial growth factor 
ic markers for MSCs were expressed by rPI-SCs such as CD29 (99.57\%), CD90 (91.79\%), CD54 (98.29\%), MHC class I (73.77\%). On the other hand, rPI-SCs did not express some of hematopoietic stem cell markers including CD45 (0.12\%) and MHC class II (0.01\%) and also CD106 (6.90\%) (Fig. 1D).

Immunoflourescence analysis revealed that, in addition to MSC markers such as vimentin (Fig. 2D), isolated rPI-SCs also expressed neural and glial cell markers including brain derived neurotrophic factor (BDNF) (Fig. 2A), GFAP (Fig. 2B), fibronectin (Fig. 2C), microtubule associated protein-2a,b (MAP2a,b) (Fig. 2E), 33-tubulin (Fig. 2F), and nestin (Fig. 2G). These cells were also expressing interleukin-1 receptor antago- nis (IL-1ra) (Fig. 2H) and EP3 (Fig. 2I), inhibitors of pro-inflammatory cytokines (Fig. 2).

\section{Survival and migration of rPI-SCs}

Four weeks after rPI-SC transplantation, the immunofluorescence microscopic analysis of transversal sections of rat spinal cords from experimental groups were performed with double staining of GFP together with vimentin, $\beta 3$-tubulin, 2',3'-cyclic-nucleotide 3'-phosphodiesterase (CNPase), S100 $\beta$, nestin, vascular endothelial growth factor (VEGF) or BDNF. In all sections of laminectomy+trauma groups, they showed negative staining for GFP (Figs. 3-7), as well as laminectomy \&
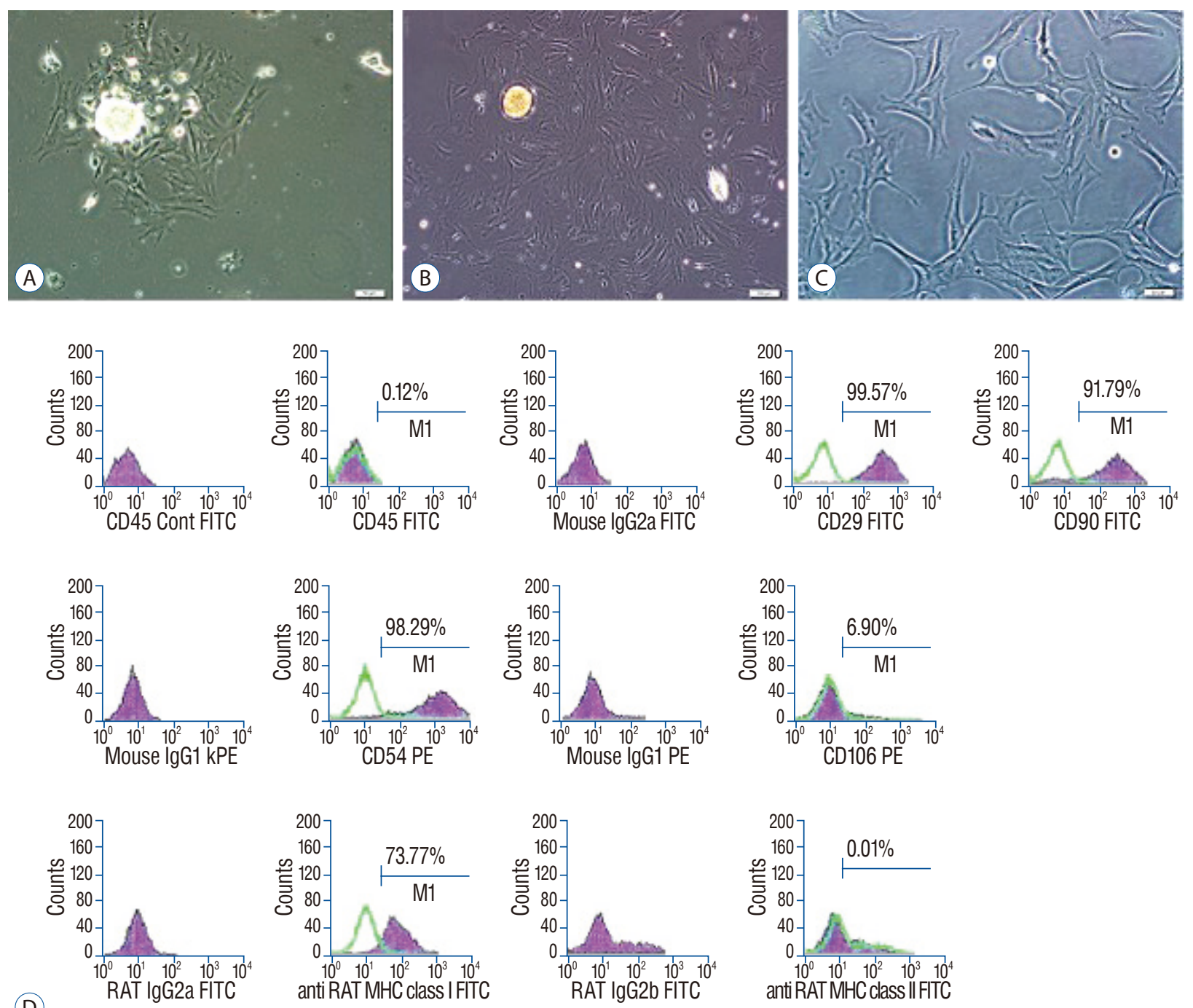

Fig. 1. Morphological characteristics of the rat pancreatic islets. Free floating rat pancreatic islets (A). Fibroblast-like cells are observed growing out and away from a pancreatic islets (B). rPI-SC morphologies (unstained) for late passage (C, P3-4th day). Flow cytometry analysis for P3 cells (C and D). Scale bars, $100 \mu \mathrm{m}$. FITC : fluorescein isothiocyanate, rPI-SC : rat pancreatic islet derived stem cell. 

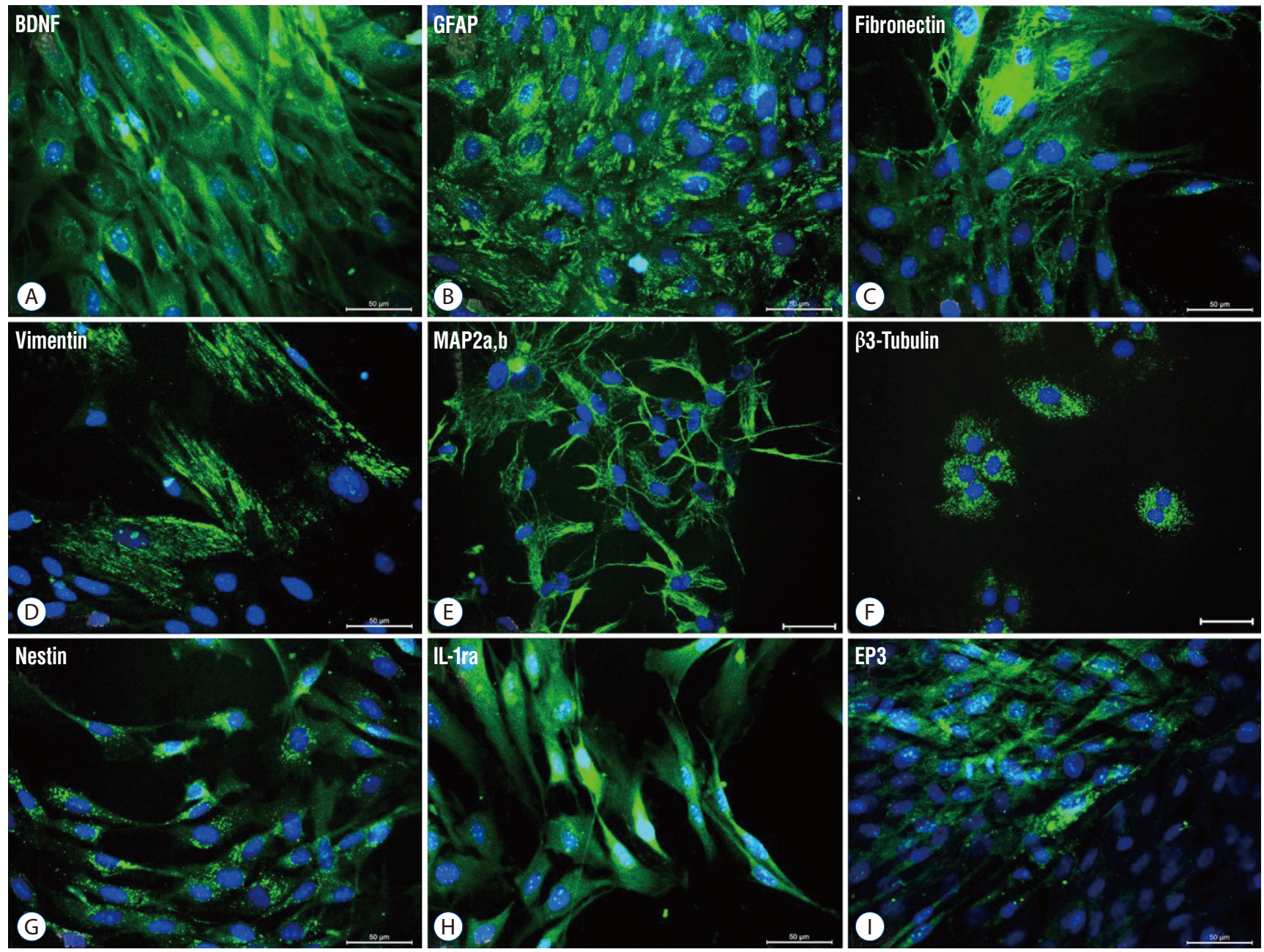

Fig. 2. Representative panels of immunofluorescence stainings for phenotype identification of rPI-SC. The expression of cell markers of neurogenic (A-C and $\mathrm{E}-\mathrm{G}$ ) and mesenchymal markers (D) and inhibitors of pro-inflammatory cytokines ( $\mathrm{H}, \mathrm{I})$. All markers were detected with FITC (green) labelled secondary antibodies. Nuclei were labeled with DAPI (blue) (Scale bars, $50 \mu \mathrm{m}$ ). BDNF : brain derived neurotrophic factor, GFAP : glial fibrillary acidic protein, MAP2a,b : microtubule associated protein-2a,b, IL-1ra : interleukin-1 receptor antagonis, FITC : fluorescein isothiocyanate, rPI-SC : rat pancreatic islet derived stem cell.

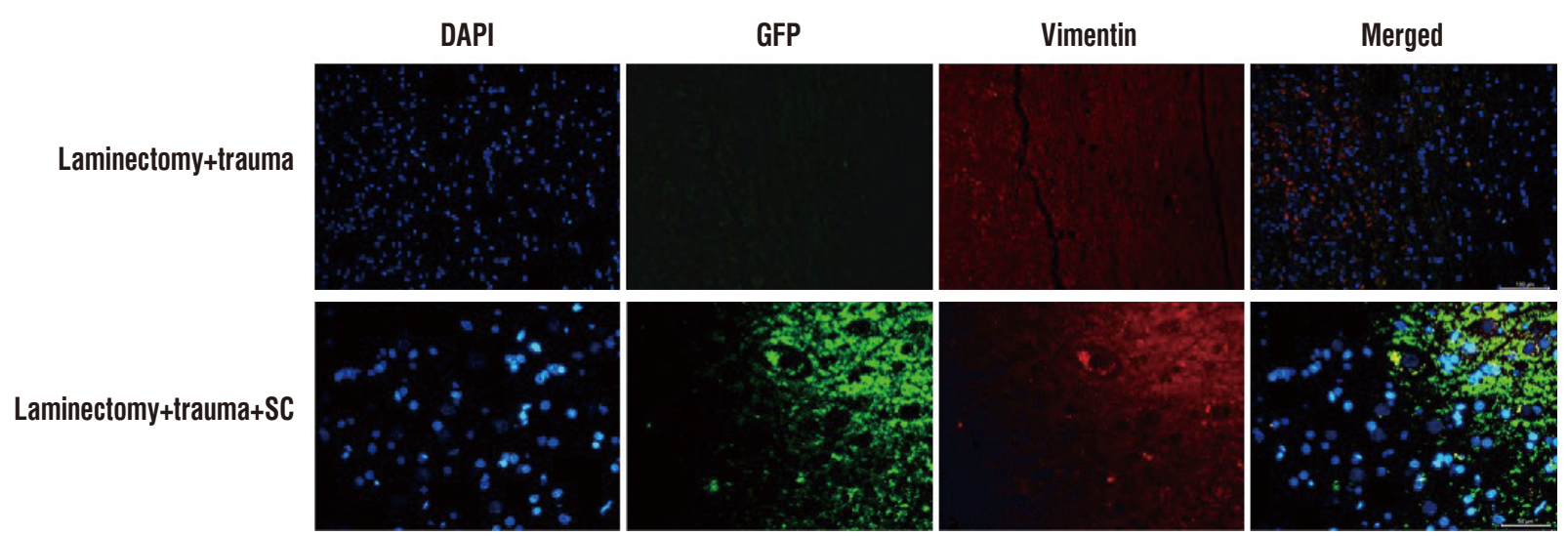

Fig. 3. Immunofluorescence stainings in paraffin sections of rat spinal cord tissues. Four weeks after rPI-SC transplantation, GFP+ cells were migrated to the damaged site and survived in laminectomy+trauma+SC (group 3) animals' sections. GFP+/vimentin+rPI-SCs were located in damaged area. Green : GFP, red : vimentin. Nuclei were labeled with DAPI (blue) (Scale bars, $50 \mu \mathrm{m}$ ). DAPI : 4',6-diamidino-2-phenylindole, dihydrochloride, GFP : green fluorescent protein, SC : stem cell, rPI-SC : rat pancreatic islet derived stem cell. 


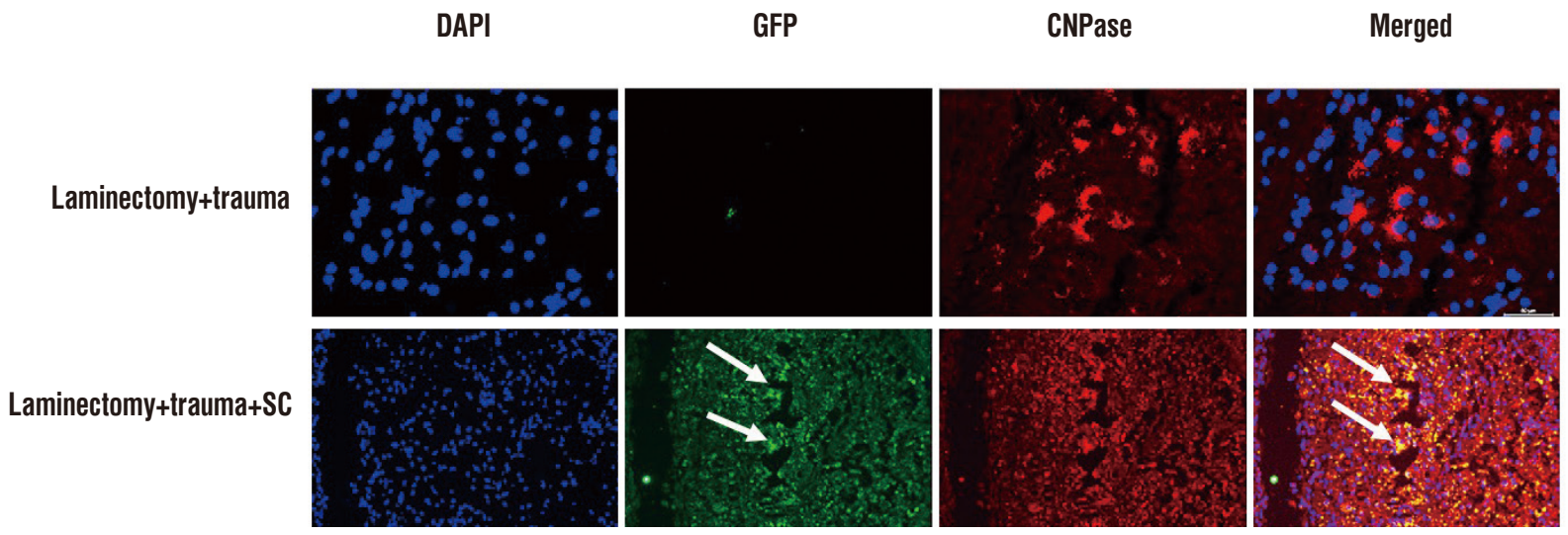

Fig. 4. Immunofluorescence stainings in paraffin sections of rat spinal cord tissues. Four weeks after rPI-SC transplantation, GFP+ cells were migrated to the damaged site and survived in laminectomy+trauma+SC (group 3) animals' sections. GFP+/CNPase+rPI-SCs were located in damaged area. Green : GFP, red : CNPase. Nuclei were labeled with DAPI (blue). Arrows indicate GFP+ cells. Scale bars is $50 \mu \mathrm{m}$. DAPI : 4',6-diamidino-2-phenylindole, dihydrochloride, GFP : green fluorescent protein, CNPase : 2',3'-cyclic-nucleotide 3'-phosphodiesterase, SC : stem cell, rPI-SC : rat pancreatic islet derived stem cell.

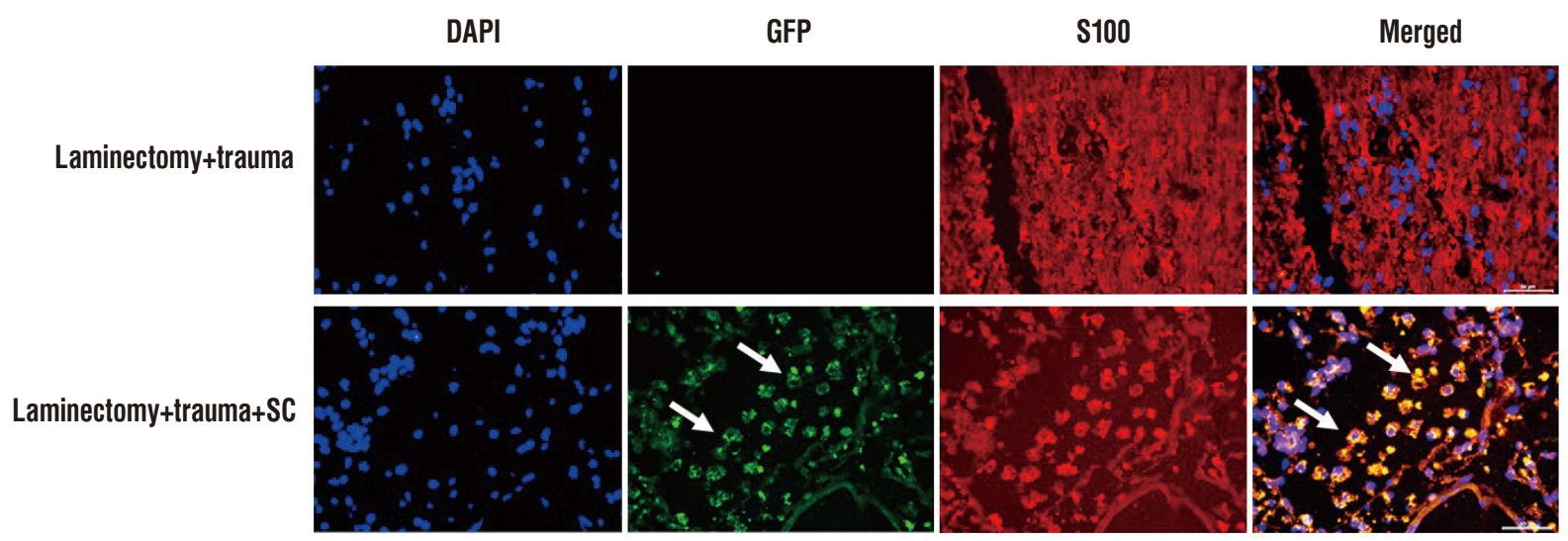

Fig. 5. Immunofluorescence stainings in paraffin sections of rat spinal cord tissues. Four weeks after rPI-SC transplantation, GFP+ cells were migrated to the damaged site and survived in laminectomy+trauma+SC (group 3) animals' sections. GFP+/S100+rPI-SCs were located in damaged area. Green : GFP, red : $S 100 \beta$. Nuclei were labeled with DAPI (blue). Arrows indicate GFP+ cells. Scale bars is $50 \mu \mathrm{m}$. DAPI : 4',6-diamidino-2-phenylindole, dihydrochloride, GFP : green fluorescent protein, SC : stem cell, rPI-SC : rat pancreatic islet derived stem cell.

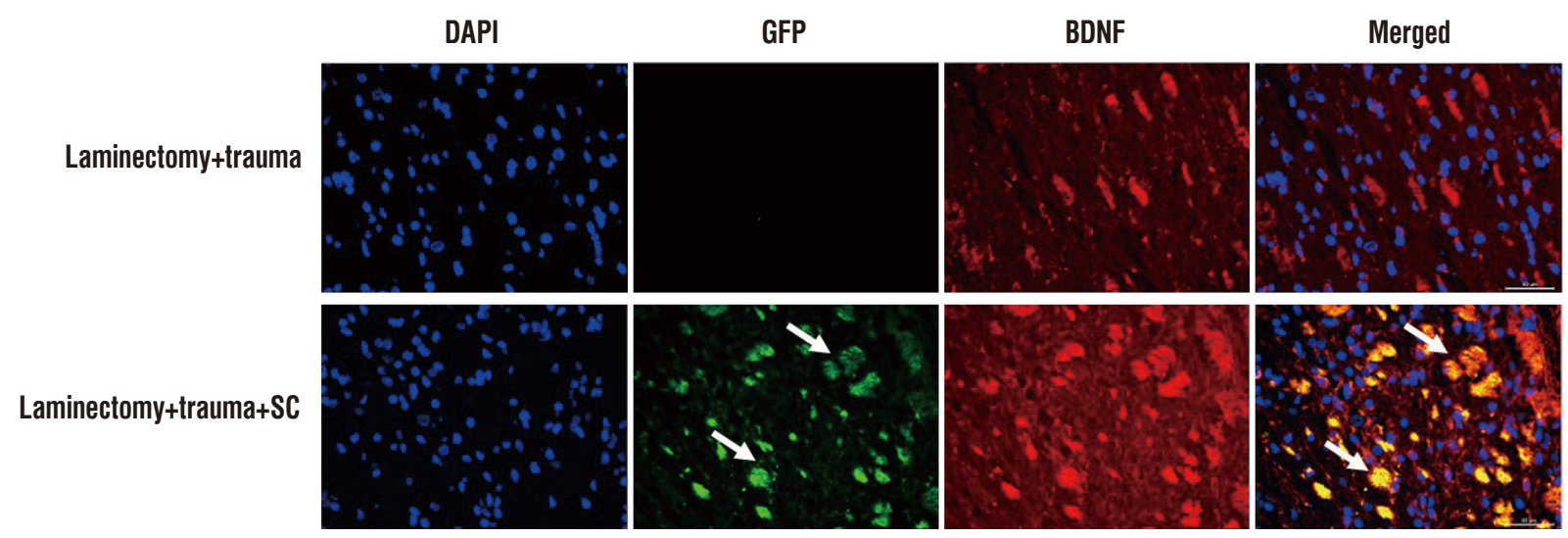

Fig. 6. Immunofluorescence stainings in paraffin sections of rat spinal cord tissues. Four weeks after rPI-SC transplantation, GFP+ cells were migrated to the damaged site and survived in laminectomy+trauma+SC (group 3) animals' sections. GFP+/BDNF+rPI-SCs were located in damaged area. Green: GFP, red : BDNF. Nuclei were labeled with DAPI (blue). Arrows indicate GFP+ cells. Scale bars is $50 \mu \mathrm{m}$. DAPI : 4',6-diamidino-2-phenylindole, dihydrochloride, GFP : green fluorescent protein, BDNF : brain derived neurotrophic factor, SC : stem cell, CNPase : 2',3'-cyclic-nucleotide 3'-phosphodiesterase, rPI-SC : rat pancreatic islet derived stem cell. 


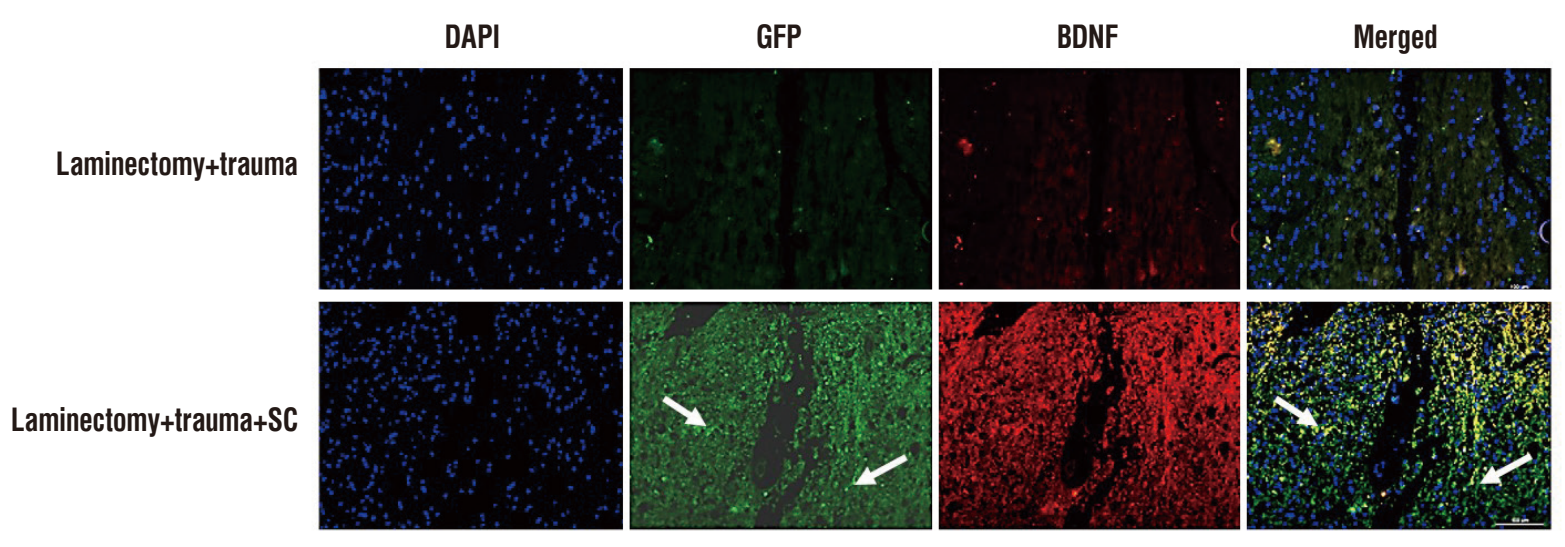

(A)

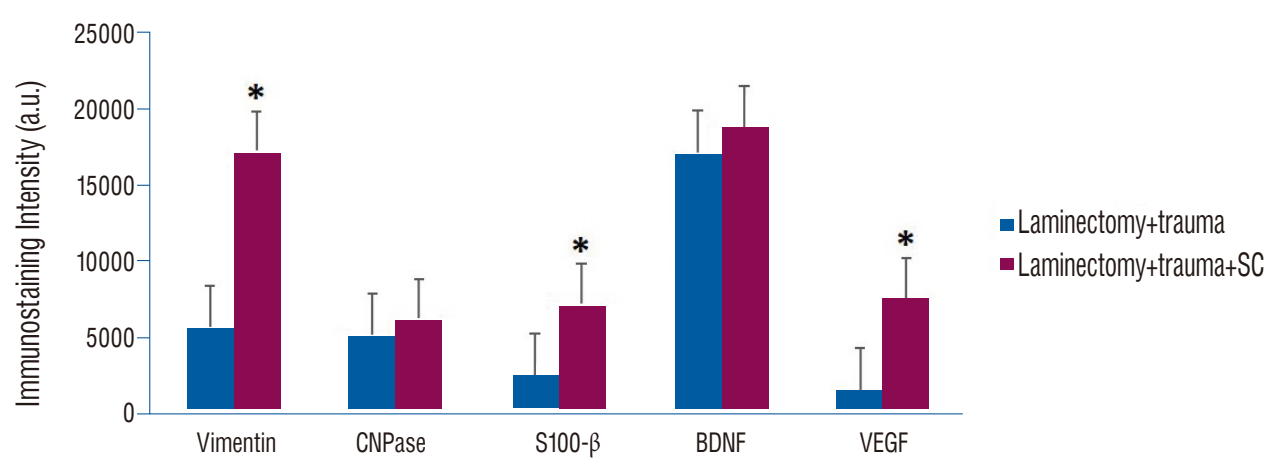

Fig. 7. A : Immunofluorescence stainings in paraffin sections of rat spinal cord tissues. Four weeks after rPI-SC transplantation, GFP+ cells were migrated to the damaged site and survived in laminectomy+trauma+SC (group 3) animals' sections. GFP+/VEGF+rPI-SCs were located in damaged area. Green : GFP, red : VEGF. Nuclei were labeled with DAPI (blue). Arrows indicate GFP+ cells. Scale bars is $50 \mu \mathrm{m}$. B : Graphs of immunostaining intensities. The values were presented as mean \pm standard error. ${ }^{*} p<0.05$. DAPI : 4',6-diamidino-2-phenylindole, dihydrochloride, GFP : green fluorescent protein, VEGF : vascular endothelial growth factor, SC : stem cell, BDNF : brain derived neurotrophic factor, a.u. : arbitrary unit, $\mathrm{rPI}$-SC : rat pancreatic islet derived stem cell.

trauma \& PBS group (data not shown). However, GFP+ cells were observed near the damage site of laminectomy+trauma+ SC group at the end of 4 weeks (Figs. 3-7). GFP+ SCs migrated into cavitated area from the injection sites and the majority of these still survived and expressed some stem cell and neural cell markers such as vimentin (Fig. 3), CNPase (Fig. 4), S-100 $\beta$ (Fig. 5), BDNF (Fig. 6), and also VEGF (Fig. 7A). Immunostaining intensity level of these factors were higher in laminectomy+trauma $+\mathrm{SC}$ group compared to laminectomy+trauma group (Fig. 7B) and laminectomy+trauma+PBS group (data not shown).

\section{Distribution of inflammatory and anti-inflamma- tory factors in the injured spinal cord}

Immunoflouresence analysis was applied to rat spinal cord sections of experimental groups. It was revealed that IL-1ra, a suppressor of proinflammatory cytokine IL-1 expression was higher in the spinal cords of rPI-SC injected group compared to the spinal cords of the rats that did not receive rPI-SCs.
Conversely, IL-6, transforming growth factor (TGF)- $\beta 1$, macrophage inflammatory protein (MIP)-2 and myeloperoxidase (MPO), indicators of inflammation, were expressed in a higher level in spinal cords of rPI-SC cell injected rats in compared to the ones without rPI-SC injection (Fig. 8).

\section{Functional recovery}

To confirm the traumatic impact of the standardized severe weight-drop contusion injury to the T10-T11 spinal cord, the hind limb locomotion of the SCI rats were evaluated. At each assessing time point, consistent functional deficits were noted among SCI rats with the BBB locomotion scores showing profound loss initially, which was then gradually improved and approaching a plateau level of spontaneous recovery typical for this type of injury by 4 weeks p.i. (Fig. 9).

According to BBB locomotor activity test, the performances of the laminectomy+trauma+SC group were statistically different from the laminectomy+trauma group $(p<0.05)$. The injured rats 


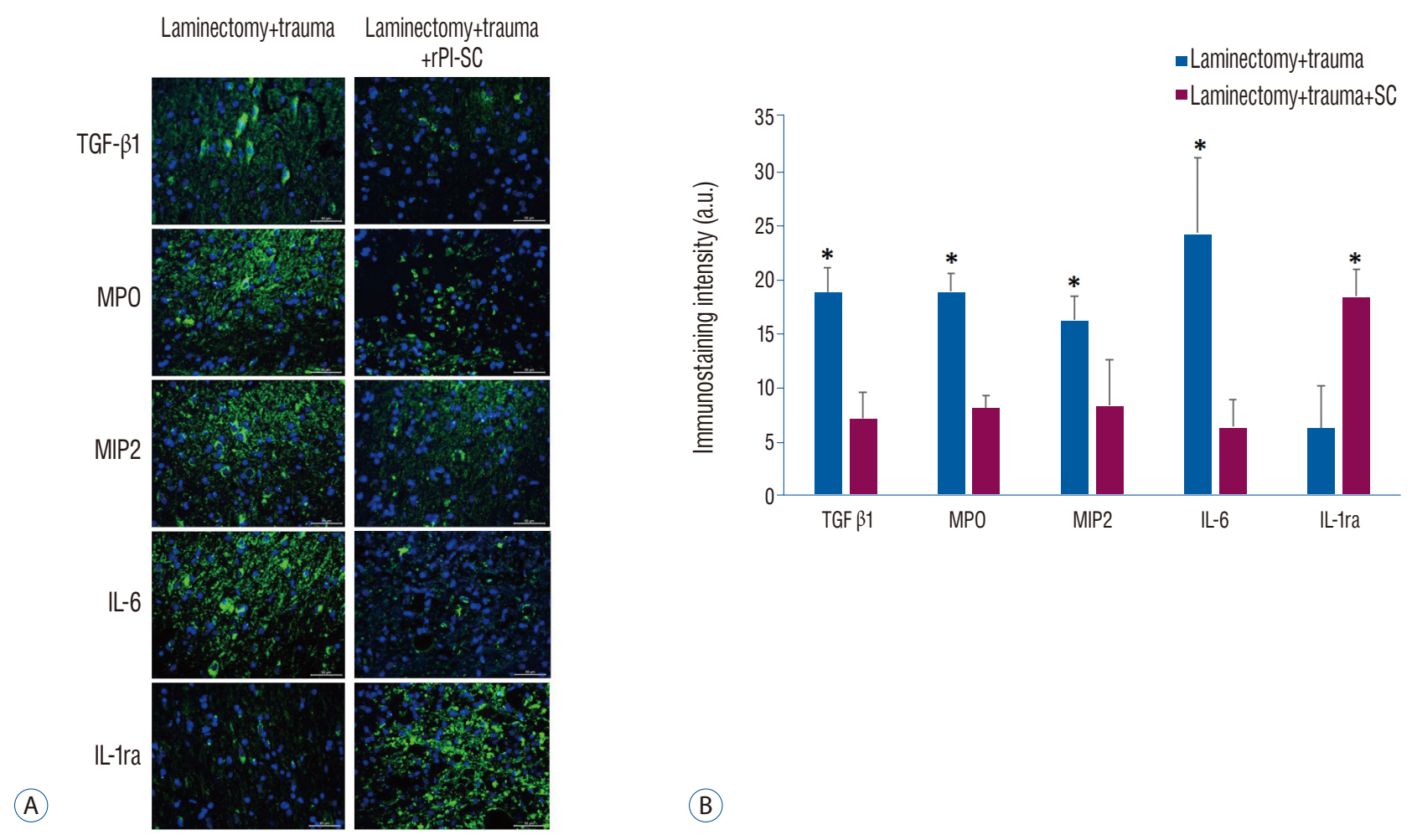

Fig. 8. A : Immunofluorescence stainings for anti-inflammatory (IL-1ra) and pro-inflammatory (IL-6, TGF- $\beta 1$, MIP-2, and MPO) markers with and without rPI-SC injection in paraffin sections of rat spinal cord. All markers were detected with FITC (green) labelled secondary antibodies. Nuclei were labeled with DAPI (blue). Scale bars is $50 \mu \mathrm{m}$. B : Graphs of immunostaining intensities. The values were presented as mean \pm standard error. ${ }^{*} p<0.05$. rPI-SC : rat pancreatic islet derived stem cell, TGF- $\beta 1$ : transforming growth factor-1, MPO : myeloperoxidase, MIP-2 : macrophage inflammatory protein-2, IL-6 : interleukin-6, IL-1ra : interleukin-1 receptor antagonis, a.u. : arbitrary unit.

BBB Score evaluation of hindlimb recovery

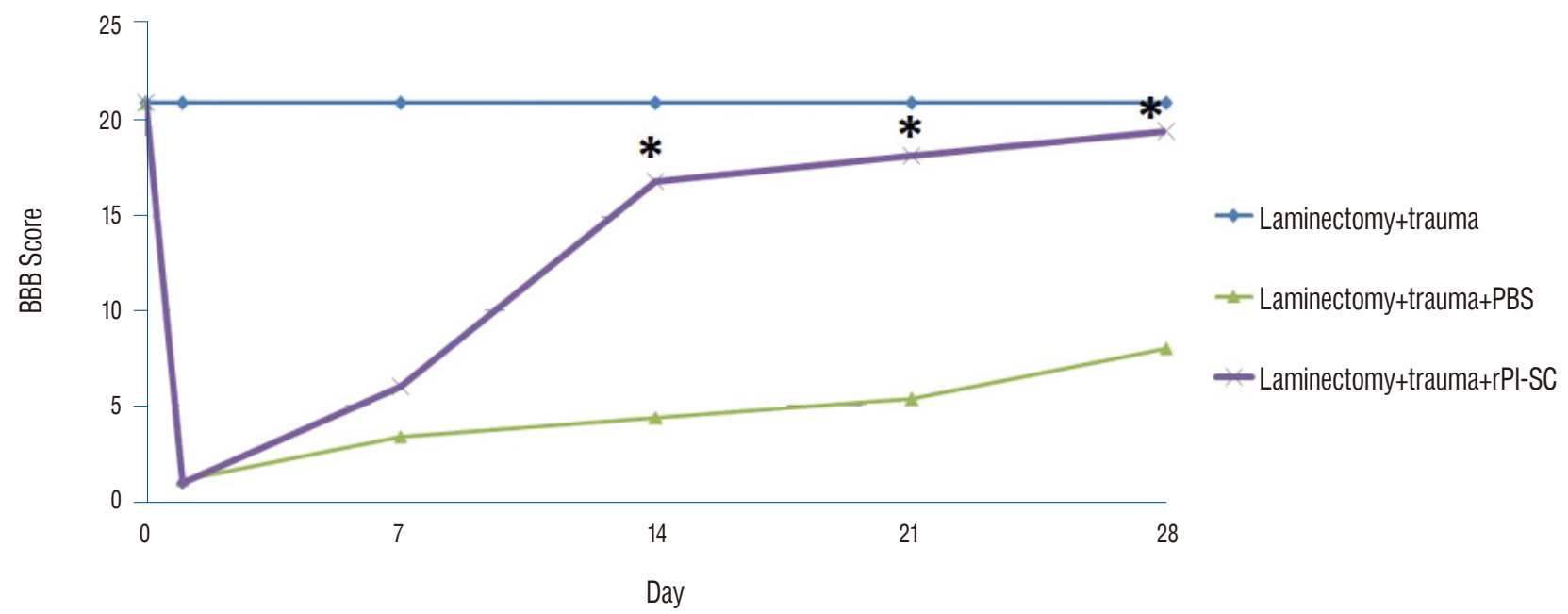

Fig. 9. The effect of $\mathrm{T} 10-\mathrm{T} 11 \mathrm{SCl}$ on general hind limb function over time after $\mathrm{SCl}$. Deficits are expressed as a BBB locomotion score. The values were presented as mean \pm standard error. ${ }^{*} p<0.05$. BBB : Basso, Beattie and Bresnahan, PBS : phosphate-buffered saline, $\mathrm{rPI}-\mathrm{SC}$ : rat pancreatic islet derived stem cell, $\mathrm{SCl}$ : spinal cord injury. 
showed marked lower activity score than MSC injected group in the BBB locomotor rating score. All experimental groups showed BBB locomotion score increment to some extent but the highest scores were observed in the stem cell injected group (Fig. 9). Hindlimb movements recorded by video camera at each assessing time points can be seen in Supplementary Video 1.

\section{DISCUSSION}

There has been considerable effort for healing SCI both with experimental models ${ }^{1)}$ and human phase 1 and 2 trials $^{48)}$ based on stem/progenitor cell transplantation. SCI is known to have an ischemic basis, complicated by an acute inflammatory and edematous tissue response ${ }^{17}$. Thus, cell-based therapy has an important role in reducing these SCI related cellular symptoms.

In some models of SCI, MSCs are suggested to reduce tissue damage, decrease cyst and injury size and improve functional outcomes $^{22}$. In our previous studies we have also shown the efficiency of bone marrow ${ }^{27)}$ and adipose tissue ${ }^{4)}$ MSCs on functional recovery following spinal cord trauma.

In the present study, we focused on PI-SCs, since pancreatic cells were reported to have regenerative capacity ${ }^{26,44,45,59)}$, suggested to result from multipotent stem cell characteristics ${ }^{44,45}$. In addition to giving rise to new pancreatic islet cells, PI-SCs were also shown to differentiate into neural cells with the capability of extensive proliferation and self-renewal ${ }^{9,45)}$.

Ontogenic origin of pancreas-derived multipotent precursors (PMPs) was considered to be the neural crest $(\mathrm{NC})^{42}$. Post-migratory NC derived cells from different regions are able to generate neuronal, glial and non-neural cell types ${ }^{57)}$. Our findings revealing that cells isolated from PI express mesenchymal markers (CD29, CD54, CD90, mhc class II, vimentin) (Figs. 1D, 2D) are consistent with previous reports ${ }^{10)}$. Since, PMPs were derived from $\mathrm{NC}^{42}$, rPI-SCs in this study might also be originated from NC and acquired MSC characteristics.

In this study it was also revealed that, cells isolated from pancreas express important components of nerve regeneration such as BDNF (Fig. 2A) and fibronectin (Fig. 2C). BDNF provides neuroplasticity, cell survival, axonal elongation, and neurite outgrowth through the activation of mitogen-activated protein kinase (MAPK), phospholipase C- $\gamma$ (PLC- $\gamma$ ), and phosphatidylinositol-3 kinase (PI3K) pathways ${ }^{6}$. Fibronectin is an extracellular matrix component known to be expressed in spinal $\operatorname{cord}^{36)}$ and fibronectin biomaterials have been developed for use in the repair of injured spinal $\operatorname{cord}^{29)}$. Expression of these factors in PI cells might have a contribution in neural regeneration in the injured spinal cord.

As reviewed by Heit and $\mathrm{Kim}^{211}$, pancreatic endocrine development was demonstrated to have numerous similarities with neural development. In the current study, rPI-SC was shown to express neural cell markers such as MAP2a,b (Fig. 2E), $\beta 3$ tubulin (Fig. 2F) and nestin (Fig. 2G), suggesting that they have a potential for neural differentiation. Since, nestin positive pancreatic cells have been shown to carry stem/progenitor cells $^{63)}$ and have neural differentiation potential ${ }^{311}$, nestin positive cells in this study might be included in neural differentiation in the injured spinal cord. Additionally, neuroprotection and neurogeneration markers such as $S 100 \beta$ (Fig. 5) and BDNF (Fig. 6), as well as oligodendrocyte marker CNPase (Fig. 4) were detected in GFP+ cells in the injury site. Isolated rPI-SC in the current study also showed GFAP expression (Fig. 2B), suggesting that these cells might differentiate into glial cells, since GFAP is an intermediate filament in mature astrocytes of the $\mathrm{CNS}^{19)}$.

Astroglial calcium-binding protein $S 100 \beta$ is predominantly found in astroglial cells ${ }^{18)}$. It has been suggested that $S 100 \beta$ in CNS tissue is involved in neuroprotection and neuroregeneration $^{43}$. Our results revealed that GFP labelled cells migrated to the injured area were $S 100 \beta$ positive (Fig. 5), suggesting that these cells could have contribute to the healing of the injured spinal cord through $S 100 \beta$.

VEGF has a pivotal role in angiogenesis and neovascularization, cell migration, inducing proliferation, repressing apoptosis as a neurotrophic factor ${ }^{41}$. Since, GFP+ cells were also shown to express VEGF (Fig. 7A), we also suggest that, rPISCs might contribute to neuro-regeneration through VEGF signaling.

An important finding revealed in our investigation was that rPI-SCs could be effective in modulating inflammatory conditions. During the secondary injury cascade of tissue destruction process following SCI, infiltrated inflammatory cells induce the release of inflammatory cytokines such as tumor necrosis factor- $\alpha$ (TNF- $\alpha$ ), IL- $1 \alpha$, IL-1 $\beta$ and IL- $6^{3,60)}$. Accordingly, control of inflammation holds promise for the improvement of SCI repair ${ }^{55)}$.

MSCs can modulate local and systemic inflammation after 
SCI where MSC treatment led to a decrease in peripheral inflammatory cell infiltration ${ }^{28}$. It was demonstrated that BMSCs seeded in scaffolds were able to decrease the distribution of blood-derived immune cells around the SCI to promote functional recovery ${ }^{56)}$. In the current study, remarkable effect of rPI-SC transplantation on hindlimb movements of the rats after SCI (Fig. 9, Supplementary Video 1), might be through the regulation of inflammation factors.

Various studies demonstrated that MSC displayed their therapeutic benefits by paracrine regulation with growth factors and cytokines for promoting vascular repair in the disease-associated situation ${ }^{2)}$. In the current study, after performing SCI, the injection of PI-SCs was likely to prevent immune cell activation and in particular to reduce the secretion of proinflammatory cytokines including IL-6, MIP-2, MPO, IL-1 $\beta$ and TGF- $\beta$ (Fig. 8) as possible direct markers of the inflammation of spinal cord. Inhibition of these inflammation factors positively affects the healing process of SCI. For instance, application of IL-6 receptor monoclonal antibody decreased the number of inflammatory cells and scar formation in mouse SCI models ${ }^{37}$. MSC-derived prostaglandin E2 was reported to act on macrophages, increasing their IL-10 secretion and reducing inflammation ${ }^{32}$. These actions of prostaglandins take place after they bind to their G-protein-coupled receptors such as $\mathrm{EP}^{52}{ }^{52}$. We demonstrated the presence of EP3 in rPI-SCs (Fig. 1I) which might be pointing out immunosuppressive activity of these cells.

In previous studies, $\mathrm{rBM}-\mathrm{MSC}$ transplantation in rats was shown to consistently attenuate the levels of pro-inflammatory cytokines including IL-6 and MIP-2 ${ }^{27)}$ and MPO $^{61}$. Németh et al. ${ }^{34)}$ demonstrated that anti-inflammatory mediators like IL-10, IL-1ra and IL-13 increased after MSC treatment. IL-1ra inhibits IL-1 that attracts neutrophils, macrophages, and lymphocytes resulting in tissue inflammation ${ }^{53)}$ and directly enhances epithelial cell survival ${ }^{38)}$. In the current study, rPI-SC administration was found to be effective for increasing the intensity of IL-1ra (Fig. 8) in the injured area of the spinal cord, suggesting an anti-inflammatory role for these cells.

Since particular factors related to neutrophil accumulation, such as MPO and MIP were previously suggested to be related with inflammation after $\mathrm{SCI}^{20)}$, suppression of these factors is an essential therapeutic step for SCI. We have shown that these factors were decreased after stem cell injection in the injured area (Fig. 8). In addition, TGF- $\beta$, which has been sug- gested to be increased after $\mathrm{SCI}^{16)}$, was also decreased after rPISC injection. The altered levels of all these factors related to inflammation after rPI-SC transplantation, provide strong evidence that rPI-SCs might have an impact on modulation of anti-inflammatory response for healing SCI.

\section{CONCLUSION}

The present study showed that transplantation of rPI-SCs into the contused spinal cord improved locomotor recovery. Reduction of inflammation factors after rPI-SCs transplantation might be effective for functional outcomes following traumatic injuries to the spinal cord. In light of the findings of the current study, we suggest that rPI-SCs can be used as a unique cellular resource for neuroregeneration therapies. The use of post-transcriptional regulators might provide further improvement in rPI-SC based cellular therapy for SCI. Because of the convincing results of applications of rPI-SCs in experimental models for functional recovery after SCI, we suggest that PI-SCs might be considered for the use in clinical trials for their therapeutic use in the injuries of human spinal cord.

\section{CONFLICTS OF INTEREST}

No potential conflict of interest relevant to this article was reported.

\section{- Acknowledgements}

The authors would like to thank Alparslan Okcu and Asst Prof. Gokhan Duruksu for their technical assistance.

\section{- Supplementary materials}

The online-only data supplement is available with this article at https://doi.org/10.3340/jkns.2018.0035.

\section{References}

1. Abdullahi D, Annuar AA, Mohamad M, Aziz I, Sanusi J : Experimental spinal cord trauma: a review of mechanically induced spinal cord injury 
in rat models. Rev Neurosci $28: 15-20,2017$

2. Aggarwal $S$, Pittenger MF : Human mesenchymal stem cells modulate allogeneic immune cell responses. Blood 105 : 1815-1822, 2005

3. Ahuja CS, Nori S, Tetreault L, Wilson J, Kwon B, Harrop J, et al. : Traumatic spinal cord injury-repair and regeneration. Neurosurgery 80 (3S) : S9-S22, 2017

4. Aras $Y$, Sabanci PA, Kabatas S, Duruksu G, Subasi C, Erguven M, et al. : The effects of adipose tissue-derived mesenchymal stem cell transplantation during the acute and subacute phases following spinal cord injury. Turk Neurosurg 26 : 127-139, 2016

5. Basso DM, Beattie MS, Bresnahan JC : A sensitive and reliable locomotor rating scale for open field testing in rats. J Neurotrauma $12: 1-21$, 1995

6. Blum R, Konnerth A : Neurotrophin-mediated rapid signaling in the central nervous system: mechanisms and functions. Physiology (Bethesda) $20: 70-78,2005$

7. Chen Y, Tang Y, Vogel LC, Devivo MJ : Causes of spinal cord injury. Top Spinal Cord Inj Rehabil $19: 1-8,2013$

8. Choi H, Liao WL, Newton KM, Onario RC, King AM, Desilets FC, et al. : Respiratory abnormalities resulting from midcervical spinal cord injury and their reversal by serotonin $1 \mathrm{~A}$ agonists in conscious rats. J Neurosci 25 : 4550-4559, 2005

9. Choi Y, Ta M, Atouf F, Lumelsky N : Adult pancreas generates multipotent stem cells and pancreatic and nonpancreatic progeny. Stem Cells 22 : 1070-1084, 2004

10. Coskun E, Ercin M, Gezginci-Oktayoglu S : The role of epigenetic regulation and pluripotency-related micrornas in differentiation of pancreatic stem cells to beta cells. J Cell Biochem 119 : 455-467, 2017

11. Davani B, Ikonomou L, Raaka BM, Geras-Raaka E, Morton RA, MarcusSamuels $B$, et al. : Human islet-derived precursor cells are mesenchymal stromal cells that differentiate and mature to hormone-expressing cells in vivo. Stem Cells 25 : 3215-3222, 2007

12. Deltour L, Leduque P, Blume N, Madsen O, Dubois P, Jami J, et al. : Differential expression of the two nonallelic proinsulin genes in the developing mouse embryo. Proc Natl Acad Sci U S A 90 : 527-531, 1993

13. Edlund $\mathrm{H}$ : Pancreatic organogenesis--developmental mechanisms and implications for therapy. Nat Rev Genet 3 : 524-532, 2002

14. Erickson GR, Gimble JM, Franklin DM, Rice HE, Awad H, Guilak F : Chondrogenic potential of adipose tissue-derived stromal cells in vitro and in vivo. Biochem Biophys Res Commun 290 : 763-769, 2002

15. García-Altés A, Pérez K, Novoa A, Suelves JM, Bernabeu M, Vidal J, et al. : Spinal cord injury and traumatic brain injury: a cost-of-illness study. Neuroepidemiology 39 : 103-108, 2012

16. Gensel JC, Zhang B : Macrophage activation and its role in repair and pathology after spinal cord injury. Brain Res 1619 : 1-11, 2015

17. Goldman SA : Stem and progenitor cell-based therapy of the central nervous system: hopes, hype, and wishful thinking. Cell Stem Cell 18 : 174-188, 2016

18. Hajduková L, Sobek $\mathrm{O}$, Prchalová D, Bilková Z, Koudelková M, Lukášková J, et al. : Biomarkers of brain damage: S100B and NSE concentrations in cerebrospinal fluid--a normative study. Biomed Res Int 2015 :
379071, 2015

19. Hajós F, Kálmán $M$ : Distribution of glial fibrillary acidic protein (GFAP)immunoreactive astrocytes in the rat brain. II. Mesencephalon, rhombencephalon and spinal cord. Exp Brain Res 78 : 164-173, 1989

20. Hausmann ON : Post-traumatic inflammation following spinal cord injury. Spinal Cord 41 : 369-378, 2003

21. Heit JJ, Kim SK : Embryonic stem cells and islet replacement in diabetes mellitus. Pediatr Diabetes 5 Suppl 2 : 5-15, 2004

22. Himes BT, Neuhuber B, Coleman C, Kushner R, Swanger SA, Kopen GC, et al. : Recovery of function following grafting of human bone marrowderived stromal cells into the injured spinal cord. Neurorehabil Neural Repair 20 : 278-296, 2006

23. Horwitz EM, Gordon PL, Koo WK, Marx JC, Neel MD, McNall RY, et al. : Isolated allogeneic bone marrow-derived mesenchymal cells engraft and stimulate growth in children with osteogenesis imperfecta: Implications for cell therapy of bone. Proc Natl Acad Sci U S A 99 : 8932-8937, 2002

24. Joe AW, Gregory-Evans K : Mesenchymal stem cells and potential applications in treating ocular disease. Curr Eye Res 35 : 941-952, 2010

25. Juan-Mateu J, Rech TH, Villate O, Lizarraga-Mollinedo E, Wendt A, Turatsinze JV, et al. : Neuron-enriched RNA-binding proteins regulate pancreatic beta cell function and survival. J Biol Chem 292 : 34663480, 2017

26. Karaoz E, Ayhan S, Gacar G, Aksoy A, Duruksu G, Okçu A, et al. : Isolation and characterization of stem cells from pancreatic islet: pluripotency, differentiation potential and ultrastructural characteristics. Cytotherapy 12 : 288-302, 2010

27. Karaoz E, Kabatas S, Duruksu G, Okcu A, Subasi C, Ay B, et al. : Reduction of lesion in injured rat spinal cord and partial functional recovery of motility after bone marrow derived mesenchymal stem cell transplantation. Turk Neurosurg 22 : 207-217, 2012

28. Kim JW, Ha KY, Molon JN, Kim YH : Bone marrow-derived mesenchymal stem cell transplantation for chronic spinal cord injury in rats: comparative study between intralesional and intravenous transplantation. Spine (Phila Pa 1976) 38 : E1065-E1074, 2013

29. King VR, Hewazy D, Alovskaya A, Phillips JB, Brown RA, Priestley JV : The neuroprotective effects of fibronectin mats and fibronectin peptides following spinal cord injury in the rat. Neuroscience 168 : 523-530, 2010

30. Lee OK, Kuo TK, Chen WM, Lee KD, Hsieh SL, Chen TH : Isolation of multipotent mesenchymal stem cells from umbilical cord blood. Blood 103 : 1669-1675, 2004

31. Lindsay SL, Barnett SC : Are nestin-positive mesenchymal stromal cells a better source of cells for CNS repair? Neurochem Int 106 : 101-107, 2017

32. Maggini J, Mirkin G, Bognanni I, Holmberg J, Piazzón IM, Nepomnaschy I, et al. : Mouse bone marrow-derived mesenchymal stromal cells turn activated macrophages into a regulatory-like profile. PLoS One 5 : e9252, 2010

33. Mothe AJ, Tator $\mathrm{CH}$ : Advances in stem cell therapy for spinal cord injury. J Clin Invest 122 : 3824-3834, 2012 
34. Németh K, Leelahavanichkul A, Yuen PS, Mayer B, Parmelee A, Doi K, et al. : Bone marrow stromal cells attenuate sepsis via prostaglandin $E(2)$-dependent reprogramming of host macrophages to increase their interleukin-10 production. Nat Med 15 : 42-49, 2009

35. Oh SK, Jeon SR : Current concept of stem cell therapy for spinal cord injury: a review. Korean J Neurotrauma 12 : 40-46, 2016

36. O'Hara CM, Egar MW, Chernoff EA : Reorganization of the ependyma during axolotl spinal cord regeneration: changes in intermediate filament and fibronectin expression. Dev Dyn 193 : 103-115, 1992

37. Okada S, Nakamura M, Mikami Y, Shimazaki T, Mihara M, Ohsugi Y, et al. : Blockade of interleukin- 6 receptor suppresses reactive astrogliosis and ameliorates functional recovery in experimental spinal cord injury. J Neurosci Res 76 : 265-276, 2004

38. Ortiz LA, Dutreil M, Fattman C, Pandey AC, Torres G, Go K, et al. : Interleukin 1 receptor antagonist mediates the antiinflammatory and antifibrotic effect of mesenchymal stem cells during lung injury. Proc Natl Acad Sci U S A 104 : 11002-11007, 2007

39. Park JR, Kim E, Yang J, Lee H, Hong SH, Woo HM, et al. : Isolation of human dermis derived mesenchymal stem cells using explants culture method: expansion and phenotypical characterization. Cell Tissue Bank 16 : 209-218, 2015

40. Parr AM, Kulbatski I, Zahir T, Wang X, Yue C, Keating A, et al. : Transplanted adult spinal cord-derived neural stem/progenitor cells promote early functional recovery after rat spinal cord injury. Neuroscience 155 : 760-770, 2008

41. Pelletier J, Roudier E, Abraham P, Fromy B, Saumet JL, Birot O, et al. : VEGF-A promotes both pro-angiogenic and neurotrophic capacities for nerve recovery after compressive neuropathy in rats. Mol Neurobiol $51: 240-251,2015$

42. Pierret C, Spears K, Maruniak JA, Kirk MD : Neural crest as the source of adult stem cells. Stem Cells Dev 15 : 286-291, 2006

43. Schultke $E$, Griebel RW, Juurlink BH : Quercetin administration after spinal cord trauma changes S-100 levels. Can J Neurol Sci 37 : 223-228, 2010

44. Seaberg RM, Smukler SR, Kieffer TJ, Enikolopov G, Asghar Z, Wheeler $M B$, et al. : Clonal identification of multipotent precursors from adult mouse pancreas that generate neural and pancreatic lineages. Nat Biotechnol 22 : 1115-1124, 2004

45. Smukler SR, Arntfield ME, Razavi R, Bikopoulos G, Karpowicz P, Seaberg $R$, et al. : The adult mouse and human pancreas contain rare multipotent stem cells that express insulin. Cell Stem Cell 8 : 281-293, 2011

46. Snyder EY, Teng YD : Stem cells and spinal cord repair. $\mathbf{N}$ Engl J Med 366 : 1940-1942, 2012

47. Suzuki $A$, Nakauchi $H$, Taniguchi $H$ : Prospective isolation of multipotent pancreatic progenitors using flow-cytometric cell sorting. Diabetes 53 : 2143-2152, 2004

48. Tator $\mathrm{CH}$ : Review of treatment trials in human spinal cord injury: issues, difficulties, and recommendations. Neurosurgery 59 : 957-982; discussion 982-957, 2006
49. Tepekoy F, Ozturk S, Sozen B, Ozay RS, Akkoyunlu G, Demir N : CD90 and CD105 expression in the mouse ovary and testis at different stages of postnatal development. Reprod Biol 15 : 195-204, 2015

50. Tobias CA, Han SS, Shumsky JS, Kim D, Tumolo M, Dhoot NO, et al. : Alginate encapsulated BDNF-producing fibroblast grafts permit recovery of function after spinal cord injury in the absence of immune suppression. J Neurotrauma 22 : 138-156, 2005

51. Uccelli A, Benvenuto F, Laroni A, Giunti D : Neuroprotective features of mesenchymal stem cells. Best Pract Res Clin Haematol 24 : 59-64, 2011

52. Vanegas $H$, Schaible HG : Prostaglandins and cyclooxygenases [correction of cycloxygenases] in the spinal cord. Prog Neurobiol 64 : 327-363, 2001

53. Volarevic V, Al-Qahtani A, Arsenijevic N, Pajovic S, Lukic ML : Interleukin-1 receptor antagonist (IL-1Ra) and IL-1Ra producing mesenchymal stem cells as modulators of diabetogenesis. Autoimmunity 43 : 255263,2010

54. Volkman $R$, Offen $D$ : Concise review: mesenchymal stem cells in neurodegenerative diseases. Stem Cells 35 : 1867-1880, 2017

55. Wang CY, Chen JK, Wu YT, Tsai MJ, Shyue SK, Yang CS, et al. : Reduction in antioxidant enzyme expression and sustained inflammation enhance tissue damage in the subacute phase of spinal cord contusive injury. J Biomed Sci 18 : 13, 2011

56. Wang YH, Chen J, Zhou J, Nong F, Lv JH, Liu J : Reduced inflammatory cell recruitment and tissue damage in spinal cord injury by acellular spinal cord scaffold seeded with mesenchymal stem cells. Exp Ther Med $13:$ 203-207, 2017

57. Wong CE, Paratore C, Dours-Zimmermann MT, Rochat A, Pietri T, Suter $U$, et al. : Neural crest-derived cells with stem cell features can be traced back to multiple lineages in the adult skin. J Cell Biol 175 : 1005-1015, 2006

58. Xie F, Zheng $B$ : White matter inhibitors in CNS axon regeneration failure. Exp Neurol 209 : 302-312, 2008

59. Xu X, D'Hoker J, Stangé G, Bonné S, De Leu N, Xiao X, Van de Casteele $M$, et al. : Beta cells can be generated from endogenous progenitors in injured adult mouse pancreas. Cell 132: 197-207, 2008

60. Yang Z, Bramlett HM, Moghieb A, Yu D, Wang P, Lin F, et al. : Temporal profile and severity correlation of a panel of rat spinal cord injury protein biomarkers. Mol Neurobiol 55 : 2174-2184, 2017

61. Yilmaz S, Inandiklioglu N, Yildizdas D, Subasi C, Acikalin A, Kuyucu Y, et al. : Mesenchymal stem cell: does it work in an experimental model with acute respiratory distress syndrome? Stem Cell Rev $9:$ 80-92, 2013

62. Zhu Y, Uezono N, Yasui T, Nakashima K : Neural stem cell therapy aiming at better functional recovery after spinal cord injury. Dev Dyn 247 : 75-84, 2017

63. Zulewski H, Abraham EJ, Gerlach MJ, Daniel PB, Moritz W, Müller B, et al. : Multipotential nestin-positive stem cells isolated from adult pancreatic islets differentiate ex vivo into pancreatic endocrine, exocrine, and hepatic phenotypes. Diabetes 50 : 521-533, 2001 